\title{
Simultaneous cleanup of Reactive Black 5 and cadmium by a desert soil bacterium
}

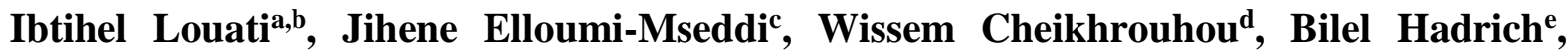
Moncef Nasria ${ }^{a}$ Sami Aifac ${ }^{c}$ and Tahar Mechichi ${ }^{\text {b* }}$

a Laboratory of Enzyme Engineering and Microbiology, National School of Engineers of Sfax, University of Sfax, BP 1173, 3038 Sfax, Tunisia.

${ }^{b}$ Laboratory of Biochemistry and Enzymatic Engineering of Lipases, National School of Engineers of Sfax, University of Sfax, 3038 Sfax, Tunisia.

${ }^{c}$ Laboratory of Molecular and Cell Screening Processes, Center of Biotechnology of Sfax, Sidi Mansour Road Km 6, BP 1177, 3018 Sfax, Tunisia

${ }^{\mathrm{d}}$ LT2S laboratory, Digital Research Center of sfax, Technopark of sfax, BP 275, 3021 Sfax, Tunisia

${ }^{\text {e } U n i t e ́ ~ d e ~ B i o t e c h n o l o g i e ~ d e s ~ A l g u e s, ~ B i o l o g i c a l ~ E n g i n e e r i n g ~ D e p a r t m e n t, ~ N a t i o n a l ~ S c h o o l ~ o f ~}$ Engineers of Sfax, University of Sfax, Tunisia.

* Correspondence to: Tahar Mechichi

E-mail: tahar.mechichi@enis.rnu.tn

Adress : ENIS route de soukra BP 1173, 3038 Sfax

Tel: 21674274088

Fax: 21674275595 
Multi-contaminated industrial wastewaters pose serious environmental risks due to high toxicity and non-biodegradability. The work reported here evaluated the ability of Pseudomonas aeruginosa strain Gb30 isolated from desert soil to simultaneously remove cadmium (Cd) and Reactive Black 5 (RB5), both common contaminants in various industrial effluents. The strain was able to grow normally and decolorize $50 \mathrm{mg} \mathrm{L}^{-1} \mathrm{RB} 5$ within $24 \mathrm{~h}$ of incubation in the presence of $0.629 \mathrm{~m} \mathrm{~mol} \mathrm{~L}^{-1}$ of $\mathrm{Cd}^{2+}$. In order to evaluate strain performance in RB5 detoxification, a cytotoxicity test using Human Embryonic Kidney cells (HEK293) was used. Cadmium removal from culture media was determined using atomic adsorption. Even in presence of $(0.115+0.157+0.401+0.381) \mathrm{m} \mathrm{mol} \mathrm{L}^{-1}$, respectively, of $\mathrm{Cr}^{6+}, \mathrm{Cd}^{2+}, \mathrm{Cu}^{2+}$ and $\mathrm{Zn}^{2+}$ in the growth medium, strain Gb30 successfully removed $35 \%$ of RB5 and $44 \%, 36 \%$, $59 \%$ and $97 \%$, respectively, of introduced $\mathrm{Zn}^{2+}, \mathrm{Cu}^{2+}, \mathrm{Cr}^{6+}$ and $\mathrm{Cd}^{2+}$, simultaneously. In order to understand the mechanism of $\mathrm{Cd}$ removal used by $P$. aeruginosa strain $\mathrm{Gb} 30$, biosorption and bioaccumulation abilities were examined. The strain was preferentially biosorbing $\mathrm{Cd}$ on the cell surface, as opposed to intracellular bioaccumulation. Microscopic investigations using AFM, SEM and FTIR analysis of the bacterial biomass confirmed the presence of various structural features, which enabled the strain to interact with metal ions. The study suggests that Pseudomonas aeruginosa Gb30 is a potential candidate for bioremediation of textile effluents in the presence of complex dye-metal contamination.

2 Keywords: dyes; heavy metals; resistance; biodegradation; co-removal; biosorption. 


\section{Introduction}

Progress in industrialization is a double-edged sword, improving the living conditions for humans, but at the same time negatively impacting the environment by discharging huge amounts of wastewater rich in organic and inorganic pollutants. Synthetic dyes and heavy metals, considered as hazardous xenobiotics, are major pollutants present in several industrial effluents (Huang et al., 2015; Ruta et al., 2010; Taştan et al., 2010). For example, Azo dyes, known to be the most widespread dyes used in several industrial processes, such as the manufacture of textiles, paints, pulp and paper, and in printing and tanning, generate highly toxic effluents (Aksu, 2005; Durai and Rajasimman, 2011; Mishra and Malik, 2014; Anwar et al., 2014; Sarker et al., 2015, Maqbool et al., 2016). As a result of these industrial processes, huge quantities of these compounds are discharged into the environment and cause serious ecological problems. Due to their chemical composition (aromatic rings, azoic linkages and amino groups), azo dyes are highly stable in both soil and aquatic environments (Imran et al., 2015). Several reports described the effects of these pollutants and their biodegradation products on living organisms (e.g. Mahmood et al., 2015). Other pollutants of great concern in industrial wastewaters are heavy metals. Cadmium is judged to be a major threat to both terrestrial and aquatic ecosystems and is present in a variety of industrial wastewaters (Pavlaki et al., 2016; Rani et al., 2014). It is considered an extremely hazardous metal due to both toxicity and carcinogenic properties, even at low doses $\left(2.72 \mu \mathrm{g} \mathrm{L}^{-1}\right)$ (Bernhoft, 2013; Feki-Tounsi et al., 2013; Lacave et al., 2020; Pizzaia et al., 2019). Recent data suggested that human exposure to $\mathrm{Cd}$ induces multi-system toxicity. It can affect the cardiovascular, immune, urinary, nervous, endocrine and reproductive systems (Bernhoft, 2013). At the cellular level, Cd exposure induces expression of oxidative stress proteins, inhibition of DNA repair systems and induction of apoptosis (Rani et al., 2014). Previous reports confirmed the co-existence of $\mathrm{Cd}$ and dyes in textile and tannery effluents (Ali et al., 2009; Fenta, 2014; Sarker et al., 2015; Tchounwou et 
al., 2012). Despite wide experimental studies of biological remediation for the removal of dyes and heavy metals in recent years (Ali and El-Mohamedy, 2012; Aryal and LiakopoulouKyriakides, 2015; Ayangbenro and Babalola, 2017; Giovanella et al., 2017; Hansda et al., 2016; Solís et al., 2012), binary contamination with dyes and heavy metals remains a large environmental threat, but removal of these pollutants using biological has received little attention (Anwar et al., 2014; Huang et al., 2015; Maqbool et al., 2016; Taştan et al., 2010).

Because industries require economically and environmentally sustainable wastewater treatments effective against a range of potential pollutants, examining the abilities of microorganisms remove organic and inorganic xenobiotics from wastewaters is an urgent issue. Thus, the aim of the work reported here was to evaluate the potential of Pseudomonas aeruginosa strain Gb30 to simultaneously remove Reactive Black 5 and $\mathrm{Cd}$ in presence of a mixture of other heavy metals. The mechanisms through which strain $\mathrm{Gb} 30$ is able to tolerate heavy metal stress was also examined.

\section{Materials and methods}

\subsection{Chemicals and reagents}

Reactive Black 5 dye was purchased from Sigma-Aldrich (Germany). A stock solution with a final concentration of $10 \mathrm{~g} \mathrm{~L}^{-1}$ was prepared. The heavy metals stock solutions used were $\mathrm{CdCl}_{2}$ (0.5 mol L-1 $), \mathrm{CuSO}_{4}\left(0.25 \mathrm{~mol} \mathrm{~L}^{-1}\right), \mathrm{K}_{2} \mathrm{Cr}_{2} \mathrm{O}_{7}\left(1 \mathrm{~mol} \mathrm{~L}^{-1}\right)$ and $\mathrm{ZnSO}_{4}\left(1 \mathrm{~mol} \mathrm{~L}^{-1}\right)$. Methanol used for HPLC was of analytical grade. 
Pseudomonas aeruginosa strain Gb 30 (KY655217.1) previously isolated from desert soil and characterized and identified in our laboratory, was selected for this work (Louati et al., 2019). Tolerance to $\mathrm{Cd}$ contamination was determined at the $\mathrm{EC}_{50}$ (10 hours) and represented the median effective concentration of $\mathrm{Cd}^{2+}$ able to cause $50 \%$ inhibition of bacterial growth after 10 hours incubation at $37^{\circ} \mathrm{C}$. Examination of RB5 decolorization in the presence of $\mathrm{Cd}$ was carried out in LB medium, the $\mathrm{pH}$ of which was adjusted using standard $\mathrm{NaOH}$ and $\mathrm{HCl}$ solutions. Cultures were inoculated with $5 \%(\mathrm{v} / \mathrm{v})$ from a pre-culture with an $\mathrm{OD}_{600 \mathrm{~nm}}$ of 1.0 and supplemented with $\mathrm{Cd}^{2+}$ at a concentration corresponding to the $\mathrm{EC}_{50}(10 \mathrm{~h})$. The initial $\mathrm{pH}$ was adjusted to 8 and $50 \mathrm{mg} \mathrm{L}^{-1}$ final concentration of dye added. Cultures were incubated at $37^{\circ} \mathrm{C}$, under static conditions. Aliquots for further analyses were withdrawn at $12 \mathrm{~h}$ intervals.

\subsection{Effect of $\mathrm{Cd}^{2+}$ on bacterial growth and dye decolorization}

Growth kinetics of control and $\mathrm{Cd}^{2+}$ containing cultures were evaluated by dry weight biomass determination during incubation. Color removal was analyzed using HPLC and UV-Visible spectroscopy. RB5 biodegradation products were examined by HPLC, using a DIONEX UltiMate 3000 (Thermo Scientific) C-18 column at room temperature. The mobile phase was water / methanol $(60 / 40 \%)$ with a flow rate of $1 \mathrm{~mL} \mathrm{~min}^{-1}$. Compounds were detected using an UV/VIS detector at $597 \mathrm{~nm}$.

Absorption of culture samples was scanned in the range of 200-800 nm using an UV-Visible spectrophotometer. Any RB5 remaining in the culture medium was determined by measuring the optical density of a sub-sample of the cultures in the range of 400-800 nm using a JENWAY $7315 \mathrm{UV} / \mathrm{Vis}$ spectrophotometer. To investigate the effect of $\mathrm{Cd}^{2+}$ ion concentration on $\mathrm{RB} 5$ removal, the decolorization rate was calculated for the first $24 \mathrm{~h}$ of incubation by plotting RB5 decolorization yield at different $\mathrm{Cd}^{2+}$ concentrations.

\subsection{Cytotoxicity assessment of RB5 decolorization products}


117 Changes in cytotoxicity was examined based on the inhibitory effect of RB5 biodegradation products on proliferation of the HEK293 (Human Embryonic Kidney cells 293) cell line. RB5 biodegradation products were obtained after incubation of $P$. aeruginosa $\mathrm{Gb} 30$ for $24 \mathrm{~h}$ under static condition at $37{ }^{\circ} \mathrm{C}$ in presence of $300 \mathrm{mg} \mathrm{L}^{-1}$ of dye. The culture medium was centrifuged at $6000 \mathrm{rpm}$ for $20 \mathrm{~min}$ at $4{ }^{\circ} \mathrm{C}$ and the supernatant filtered through $0.45 \mu \mathrm{m}$ filters before using directly in the cytotoxicity assays. Cultures without dye and with untreated RB5 (300 mg L $\left.\mathrm{L}^{-1}\right)$ were considered as negative and positive controls, respectively. HEK293 cells were cultured in 96-well plates, containing DMEM supplemented with $10 \%$ foetal bovine serum, $50 \mathrm{IU} \mathrm{mL}^{-1}$ penicillin, $50 \mathrm{mg} \mathrm{mL}-1$ streptomycin, and incubated at $37{ }^{\circ} \mathrm{C}$ in a humidified $5 \% \mathrm{CO}_{2}$ atmosphere until $40 \%$ confluence. The appropriate concentrations of the prepared samples were added and cell cultures incubated for 48 hours. Culture run added with DMEM corresponds to negative response.

\subsubsection{MTT assay}

The MTT test, based on the reduction of 3-(4,5-dimethylthiazol-2-yl)-2,5-diphenyltetrazolium bromide (MTT) into purple formazan crystals by succinate dehydrogenase in the mitochondrial respiratory chain of the HEK293 cells, was used to assess viability. After incubation, the culture medium was removed and cells washed twice in PBS1X. Fresh medium (100 $\mu$ L) containing $10 \mu \mathrm{L}$ MTT solution (5 mg mL $\mathrm{m}^{-1}$ in PBS) was added. Four hours later, in order to dissolve the formazan, $100 \mu \mathrm{L}$ of $10 \%$ SDS solution was added to each well. Optical density was measured at $570 \mathrm{~nm}$ using a Varioskan microplate reader (Thermofisher). Percentage cell survival in the presence of untreated and degraded RB5 was calculated as follows:

cell survival $(\%)=\frac{A_{T}}{A_{C}} * 100$

Where:

$A_{T}:$ is the absorbance at $570 \mathrm{~nm}$ of treated cells 
158

$A_{C:}$ is the absorbance at $570 \mathrm{~nm}$ of control cells

\subsection{Heavy metal removal}

\subsubsection{Metal removal kinetics}

Residual $\mathrm{Cd}^{2+}$ ion concentration in the culture medium was determined by atomic absorption (Fisher Scientific ice 3000) at 12 hour intervals. To investigate the adsorption process, pseudo-first and pseudo-second order kinetic models were fitted to the experimental data. The pseudo-first order model equation proposed by Lagergren (Lagergren, 1898) assumes that the rate of occupation of sorption sites is proportional to the number of unoccupied sites and is expressed as follows:

$q=q_{e q} \cdot\left(1-e^{-k_{1} \cdot t}\right)$

Where

$q$ : quantity of Cd biosorbed per unit of mass of cells

$q_{e q}:$ quantity of Cd biosorbed per unit of mass of cells at equilibrium

$k_{1}\left(\min ^{-1}\right)$ is the adsorption rate constant.

The pseudo-second order model described by Ho and McKay (Ho and McKay, 1999) assumes that adsorption follows second order chemisorption. This model was used to explain the sorption kinetics using the following expression:

$q=\frac{k_{2} \cdot q_{e q}^{2} \cdot t}{1+k_{2} \cdot q_{e q} \cdot t}$

where $k_{2}\left(\mathrm{~g} \mathrm{mg}^{-1} \mathrm{~min}\right)$ is the adsorption rate constant of the pseudo-second order adsorption.

Cd removal in the presence of a mixture of three heavy metals $\left(\mathrm{Zn}^{2+}, \mathrm{Cu}^{2+}\right.$ and $\left.\mathrm{Cr}^{6+}\right)$, containing $\mathrm{EC}_{50}(10 \mathrm{~h}) / 4$ of each heavy metal concentration (equivalent to $0.115+0.157+0.401+0.381$ $\mathrm{m} \mathrm{mol} \mathrm{L} \mathrm{L}^{-1}$ of $\mathrm{Cr}^{6+}, \mathrm{Cd}^{2+}, \mathrm{Cu}^{2+}$ and $\mathrm{Zn}^{2+}$, respectively, was also investigated. The ability of strain Gb30 to remove several heavy metals simultaneously was assessed by atomic adsorption analysis of residual heavy metals in the mixture. 
In order to understand Cd uptake by $P$. aeruginosa strain Gb30, adsorption of the metal to the bacterial surface and accumulated inside the cell was determined. Briefly, LB culture medium containing $\mathrm{EC}_{50}(10 \mathrm{~h}) \mathrm{CdCl}_{2}$ and $50 \mathrm{mg} \mathrm{L}^{-1} \mathrm{RB} 5$ was inoculated with $5 \%$ from a culture of strain $\mathrm{Gb} 30(\mathrm{DO}=1.0)$ and incubated for $24 \mathrm{~h}$ at $37^{\circ} \mathrm{C}$. After incubation, bacterial cells were harvested by centrifugation at $6000 \mathrm{rpm}, 4^{\circ} \mathrm{C}$, and washed 3 times in milliQ water with repeated centrifugation. Subsequently, the pellet was suspended in $10 \mathrm{~mL}$ of $20 \mathrm{Mmol} \mathrm{L} \mathrm{L}^{-1}$ ethylenediaminetetraacetic acid (EDTA) and left-over night for desorption of the cell surface bound $\mathrm{Cd}$. After centrifugation, the quantities of $\mathrm{Cd}$ accumulated inside the cells and adsorbed on the cell surface were measured in the bacterial pellet and the supernatant by atomic absorption (Fisher Scientific ice 3000).

\subsubsection{Morphological analysis}

\subsubsection{Fourier transform infrared spectroscopy (FTIR)}

In order to investigate the potential functional groups responsible for $\mathrm{Cd}^{2+}$ ion uptake on Pseudomonas aeruginosa, bacterial biomass grown in the presence and in absence of $\mathrm{Cd}^{2+}$ was collected, washed twice in milliQ water, lyophilized and the IR spectrum recorded in the range 650-4000 $\mathrm{cm}^{-1}$ on a Cary 630 FTIR, Agilent technologies spectrophotometer.

\subsubsection{Scanning Electron Microscopy (SEM)}

The effect of heavy metals on bacterial cell morphology was examined using SEM. Bacterial pellets were prepared from cultures with and without $\mathrm{Cd}$, as described above, fixed in $4 \%$ formaldehyde in phosphate buffer for $30 \mathrm{~min}$ and washed three times in $0.1 \mathrm{~mol} \mathrm{~L}^{-1}$ phosphate buffer solution $(\mathrm{pH} 7.4)$. Samples were dehydrated in serial ethanol dilutions $(25 \%, 50 \%, 60$ $\%, 70 \%, 80 \%, 90 \%$ and $100 \%$ ) before sputter coating (cathodic spraying) with gold. Cell morphology was evaluated using a JEOL (JFC-1100E) scanning electron microscope using an accelerating voltage of $15 \mathrm{kV}$. 
192 AFM analysis of cells grown in control cultures and in heavy metal-stressing conditions is a

193 means of assessing toxicity. Damaged cell morphology can clearly illustrated using AFM through high resolution topographical images of cell surfaces. For AFM analysis samples were prepared according to Chao and Zhang (2011). Bacteria cultured in presence and absence of $\mathrm{Cd}^{2+}$ ions were harvested and washed twice in PBS, fixed in $4 \%$ paraformaldehyde, washed in deionized water and placed on a previously prepared clean glass slide for air drying. Glass slides were left overnight in ethanol/HCl (70:1/v:v) before sonicating twice for $10 \mathrm{~min}$ in sterilized deionized water. The washed slides were dried at room temperature in sterile Petri dishes. AFM micrographs were recorded with silicon cantilever Tap190Al-G with force constant $48 \mathrm{~N} / \mathrm{m}$, in the distance mode via the Nanosurf Easyscan 2 Controller. The data generated from some of the AFM height images were used to calculate surface roughness of the bacterial cell exterior. The root mean square $\left(\mathrm{R}_{\mathrm{rms}}\right)$, corresponding to the roughness of the samples, was calculated with the following expression:

$R_{r m s}=\sqrt{\sum_{i=1}^{N} \frac{\left(z_{i}-z_{m}\right)^{2}}{(N-1)}}$

where, $N$ is the total number of data points, $z_{i}$ is the roughness of the $i^{\text {th }}$ point, $z_{m}$ is the average roughness.

\subsection{Statistical analysis}

Data were summarized as the mean $\pm \mathrm{SD}$ of three independent experiments. Comparisons between treatments for all experiments were performed using the Student's test, with significance at $\mathrm{P} \leq 0.05$. 
Kinetics models as well as parameter estimation for each model were fitted to non-linear regression models using Matlab R2010a (The Math Works, USA) software. The quality of fit for each model fitting was tested by calculating coefficient of determination $\left(R^{2}\right)$, adjusted coefficient of determination $\left(\mathrm{R}^{2}{ }_{\text {adj }}\right)$, root mean squared error (RMSE) and sum of squared error of prediction (SSE). The best model was chosen from the comparison between the four defined statistical criteria.

\section{Results and discussion}

\subsection{Effect of $\mathrm{Cd}^{2+}$ ions on growth and RB5 decolorization}

The effect of addition of $\mathrm{Cd}^{2+}$ on growth and decolorization ability of $P$. aeuriginosa Gb30 was examined. In the first ten hours of incubation, the $\mathrm{EC}_{50}(10 \mathrm{~h})$ of $\mathrm{CdCl}_{2}$ was estimated to be 0.629 $\mathrm{m} \mathrm{mol} \mathrm{L}{ }^{-1}$. At this concentration, bacterial growth was slightly affected for the first $24 \mathrm{~h}$, but proceeded normally for the next $48 \mathrm{~h}$ compared to $\mathrm{Cd}$-free cultures. As decolorization was a rapid process, RB5 removal from the culture medium in presence of $\mathrm{EC}_{50}(10 \mathrm{~h})$ of $\mathrm{CdCl}_{2}$ was affected in the first $12 \mathrm{~h}$ of incubation, but reached a maximum at $24 \mathrm{~h}$ (Fig.1). After $12 \mathrm{~h}$ incubation, $75 \%$ and $25 \%$ of the initial RB5 concentration was removed in the Cd-free and Cdcontaining cultures, respectively; totally degradation had occurred by $24 \mathrm{~h}$ for both cultures. UV-Vis spectra of RB5 decolorization over $72 \mathrm{~h}$ confirmed that decolorization was total finished within the first $24 \mathrm{~h}$ of incubation (Fig.2). Compared to the untreated dye, HPLC spectra of RB5 biodegradation in the presence $\mathrm{Cd}^{2+}$ after $24 \mathrm{~h}$ of incubation confirmed the total degradation of the dye; new peaks that appeared in the spectra corresponded to the degradation products (Fig.2). Decolorization rate was slightly decreased in cultures as the $\mathrm{Cd}^{2+}$ ion concentrations reached $100 \mathrm{mg} \mathrm{L}^{-1}$. The decolorization rate decreased from 2.25 to $1.7 \mathrm{mg} \mathrm{L}^{-1}$ $\mathrm{h}^{-1}$ between Cd concentrations from zero to $100 \mathrm{mg} \mathrm{L}^{-1}$. Above this concentration, a sharp decrease in the decolorization rate occurred, and the process was totally inhibited at $250 \mathrm{mg} \mathrm{\textrm {L } ^ { - }}$ 1. 
Increasing concentrations of $\mathrm{Cd}^{2+}$ ions also extended the lag phase for decolorization (Soni et

242 al., 2014). Although Cd is known to be toxic through disruption of the cellular enzymatic systems and oxidative damage to DNA (Gui et al., 2017), strain Gb30 exhibited high resistance toward $\mathrm{Cd}^{2+}$ ions and decolorization processed normally at high $\mathrm{Cd}$ concentrations. This result suggests the existence of an efficient enzymatic system able of degrading azo dyes co-existing in solution with $\mathrm{Cd}$. Increasing heavy metal concentrations in culture media damages cell growth, probably based on competition by $\mathrm{Cd}^{2+}$ ions for metabolic sites in enzymes such as reductases, which require essential metals for activity. There are previous reports on the ability of $P$. aeruginosa strains to decolorize dyes in the presence of different heavy metals (Maqbool et al., 2016; Soni et al., 2014).

\subsection{Cytotoxicity assessment of RB5 decolorization products}

\subsubsection{MTT test}

Survival of HEK293 cells in cultures to which RB5 biodegradation products were added was significantly higher $(\mathrm{p} \leq 0.05)$ compared to cells cultured in the presence of $300 \mathrm{mg} \mathrm{L}^{-1}$ untreated dye (Fig.3). At a concentration of $300 \mathrm{mg} \mathrm{L}^{-1}$, the azo dye clearly caused a cytotoxic response, decreasing cell viability by $50 \%$ with respect to the control treatment, while the biodegradation products were less toxic to HEK293. Although several previous studies suggested that decolorization does not always lead to detoxification (Ben Mansour et al., 2009; Dellai et al., 2013), the results obtained in the present work confirmed that $P$. aeruginosa Gb30 was able not only to decolorize but also to detoxify RB5. Similar findings were obtained by Kolekar and Kodam (2012) based on the MTT assay using the L-929 cell line to evaluate degradation products of Reactive Blue 59 by Alishewanella sp. KMK6.

\subsection{Cd removal in multi-heavy metal containing medium}


Examination of $\mathrm{Cd}$ removal in dye-containing medium over $72 \mathrm{~h}$ demonstrated that strain $\mathrm{Gb} 30$ removed more than $50 \%$ and $70 \%$ of the $0.629 \mathrm{~m} \mathrm{~mol} \mathrm{~L}^{-1}$ of added $\mathrm{Cd}$, respectively, within 12 and $24 \mathrm{~h}$. Cd uptake was constant for the remaining $48 \mathrm{~h}$ of incubation. These data showed that both pseudo-first and pseudo-second order models correlated well with the experimental findings (Table 1). However, the pseudo-first-order model was found to fit most closely (R2 $\geq$ 0.989), compared with the second model. These results suggest that the Lagergren kinetic model best described the adsorption of $\mathrm{Cd}$ onto bacterial biomass. The media containing multiple metals in mixture $\left(0.115+0.157+0.401+0.381 \mathrm{~m} \mathrm{~mol} \mathrm{~L}^{-1}\right.$ of $\mathrm{Cr}^{6+}, \mathrm{Cd}^{2+}, \mathrm{Cu}^{2+}$ and $\mathrm{Zn}^{2+}$, respectively) showed that $\mathrm{Cd}$ was removed to a greater extent than the other heavy metals. Strain Gb30 not only removed the dye-Cd complex from the culture medium, but also removed other metal ions, reducing concentrations of $\mathrm{Zn}^{2+}, \mathrm{Cu}^{2+}, \mathrm{Cr}^{6+}$ and $\mathrm{Cd}^{2+}$ by 44, 36, 59 and 97\%, respectively, at the same time (Fig.4). Cd removal was $97 \%$ in the first $12 \mathrm{~h}$ of culture, despite the presence of other heavy metals in the culture medium (Fig. 4). However, exposure to multiple metal ions clearly reduced RB5 degradation, as the decolorization yield was only $35 \%$ after $24 \mathrm{~h}$ of incubation (data not shown). The decrease in Cd uptake from $0.44 \mathrm{~m} \mathrm{~mol} \mathrm{~L}^{-1}$ in the single metal solution as compared to to $0.15 \mathrm{~m} \mathrm{~mol} \mathrm{~L}^{-1}$ in the multi-metal containing culture can be attributed to saturation of metal-binding sites responsible for heavy metal uptake on the cell surface (Giovanella et al., 2017). This study was unique in that $P$. aeruginosa Gb30 efficiently and simultaneously removed Cd and RB5 in a binary system and co-eliminated the dye and four heavy metals in a complex mixture.

\subsection{Cd removal mechanism}

To understand how $P$. aeruginosa Gb30 was able to resist or tolerate the presence of heavy metals in complex dye-metal contaminated mixtures, biosorption and bioaccumulation mechanisms were assessed. Quantification of $\mathrm{Cd}$ in pelleted bacteria and the associated 
supernatant after metal desorption with EDTA solution demonstrated that almost all added Cd was present in the supernatant; it was not detected in the cell pellet. Incubation of the bacterial cells in the presence of EDTA, a metal chelating agent, resulted in desorption of $\mathrm{Cd}$ from the cell walls and release into the supernatant. Clearly, the $\mathrm{Cd}$ accumulated onto the bacterial cell surface suggesting that $\mathrm{Cb} 30$ used biosorption to avoid heavy metal transport across the cell membrane, instead of accumulating Cd inside the cell. Giovanella et al. (2017) obtained similar results, confirming that large amounts of $\mathrm{Cd}, \mathrm{Ni}$ and $\mathrm{Pb}$ accumulated on the surface of Pseudomonas sp. B50D cell walls.

Cd biosorption onto bacterial biomass was previously described by Huang and Liu (2013) and Ziagova et al. (2007). Cd binding occurs by a combined or single biosorption process, including physical adsorption, ion exchange, complex formation and precipitation (Ayangbenro and Babalola, 2017; Hansda et al., 2016). In Gram-negative bacteria, cell membrane phosphate groups in phospholipids and lipo-polysaccharides were the primary sites for metal binding (Beveridge and Murray 1980). Moreover, Pseudomonas species are well known for their abilities to synthesize extracellular polymers with important roles in metal chelation (Gupta and Diwan, 2017). Giovanella et al., (2017) showed that Pseudomonas sp. B50D used reduction, biosorption, siderophore production and biofilm formation in the bio-removal of metals.

\subsection{Morphological characterization}

\subsubsection{FTIR}

FTIR scanning of Pseudomonas aeruginosa biomass revealed the presence of all the typical peaks corresponding to the major cell components (lipids, proteins, nucleic acids and carbohydrates) with functional groups including carboxyl, hydroxyl, aldehydes, ketones amide and phosphates which may be involved in heavy metal uptake (Fig.5). In the $3800-2800 \mathrm{~cm}^{-1}$ region several bands were prominent: the band at $3272 \mathrm{~cm}^{-1}$ corresponded to stretching 
vibration of bonded- and non-bonded hydroxyl groups and water. Peaks at 2924 and $2848 \mathrm{~cm}^{-}$

${ }^{1}$ indicated the presence of both symmetrical and asymmetrical C-H stretching, corresponding to aliphatic methylene groups. The sharp peak at $1641 \mathrm{~cm}^{-1}$ is attributed to stretching vibration by $\mathrm{C}=\mathrm{C}, \mathrm{C}=\mathrm{O}$ and $\mathrm{COO}$ - groups of cyclic alkenes, ketones, aldehydes and carboxylic acids. The peak at $1540 \mathrm{~cm}^{-1}$ could be explained by the presence of amide I and amide II stretching in cell proteins, whereas the peak at $1457 \mathrm{~cm}^{-1}$ was due to $\mathrm{CH}_{2}$ binding of lipids. The peak at 1394 $\mathrm{cm}^{-1}$ is due to vibration of $\mathrm{C}-\mathrm{O}$ groups in carboxylate ions. Nucleic acid and phospholipids cause asymmetric stretching of $\mathrm{PO}_{2}^{-}$groups, producing a peak at $1235 \mathrm{~cm}^{-1}$. Vibration of C-O$\mathrm{C}, \mathrm{C}-\mathrm{O}, \mathrm{C}-\mathrm{O}-\mathrm{H}, \mathrm{C}-\mathrm{O}-\mathrm{P}$ groups in esters, phosphodiesters and polysaccharides results in a peak at $1077 \mathrm{~cm}^{-1}$.

FTIR analysis of $P$. aeruginosa cell biomass showed differences between Cd-treated and control cells. There was a small decrease in the band at $1077 \mathrm{~cm}^{-1}$ and new peaks appeared at $1028 \mathrm{~cm}^{-1}$ and $891 \mathrm{~cm}^{-1}$, indicating increases in phosphodiesters and polysaccharides involved in metal binding on the cell surface . $\mathrm{C}-\mathrm{OH}$, and $\mathrm{C}-\mathrm{O}-\mathrm{C}$ groups may also be involved in $\mathrm{Cd}$ binding (Tarangini, 2009). These results agree with reports demonstrating extracellular polymeric substances (EPS) produced by microorganisms in complex formation with heavy metals. For example, Boggs et al. (2016) showed that cell-bound EPS of Pseudomonas sp. strain EPS-1W facilitated redox transformation and sorption of $\mathrm{Pu}$ on the cell surface.

Pseudomonas aeruginosa Gb30 cells were rod-shaped with a smooth surface when cultivated in Cd-free medium. Cells formed agglomerates and dividing cells were present. Following exposure to $70 \mathrm{mg} \mathrm{L}^{-1} \mathrm{Cd}^{2+}$, little change in cell size was observed (Fig.6). Size reduction is considered a mechanism adopted by micro-organisms to cope with the environmental stress; similar findings were reported by Naik and Dubey (2011) and Zeng et al. (2009), respectively, 
when $P$. aeruginosa strain $4 \mathrm{EA}$ was exposed to $0.8 \mathrm{mM} \mathrm{Pb}$ or $P$. aeruginosa strain $\mathrm{E}_{1}$ was cultured in medium with $3 \mathrm{~m} \mathrm{~mol} \mathrm{~L}^{-1} \mathrm{Cd}$. A significant reduction in Pseudomonas sp. B50D cell size when exposed to $1 \mathrm{~m} \mathrm{~mol} \mathrm{L^{-1 }}$ Cd was also described by Giovanella et al., (2017). Further morphological changes were also previously described, including increases in cell fimbriae (Giovanella et al., 2017) or the formation of filamentous shapes (Chakravarty and Banerjee, 2008; Mohamed Fahmy Gad El-Rab et al., 2006).

\subsubsection{AFM}

Surface changes on Cd-treated P. aeruginosa Gb30 cells were investigated using AFM microscopy in comparison with untreated cells. The length, width and height of the control cells were $1.23 \pm 0.13,0.63 \pm 0.06$ and $0.517 \pm 0.08 \mu \mathrm{m}$, respectively. In the presence of $70 \mathrm{mg} \mathrm{L}^{-1} \mathrm{Cd}$, no significant changes in cell length, width or height occurred ( $\mathrm{P} \geq 0.05)$, corroborating the SEM results. To evaluate the impact of $\mathrm{Cd}$ on the cell surface, roughness analysis was used, as the measurement describes changes in surface topography. Consistent with the adsorption analysis results, the surface of control cells was relatively homogeneous with an $R_{\text {rms }}$ value $=32.53 \pm 4.72$ $\mathrm{nm}$ but on exposure to Cd became significant heterogeneity with an $\mathrm{R}_{\mathrm{rms}}$ value $=65.14 \pm 12.94$ $\mathrm{nm}(\mathrm{P} \leq 0.05)$. These results supported the previous suggestion that $\mathrm{Cd}$ removal by strain $\mathrm{Gb} 30$ included surface adsorption. Although external proteins and lipopolysaccharides regulate surface changes of Gram-negative bacteria in stressful conditions, Ramya and Thatheyu (2018) reported that exposure of bacteria to heavy metals leads to changes in the surface architecture of the outer membrane as reflected by an increase in roughness.

\section{Conclusion}

Co-removal of dyes and heavy metals by Pseudomonas aeruginosa Gb30 in culture was demonstrated. The bacterial strain exhibited effectively removed Cd from culture fluids, with simultaneously detoxifying the dye RB5. The strain was highly tolerant/resistant to the presence 
of a heavy metals mixture, and able to remove zinc, copper and chromium ions in addition to

Cd. The mechanism of Cd removal was adsorption. The performance of $P$. aeruginosa $\mathrm{Gb} 30$ in simultaneous removal of dyes and heavy metals makes the strain an attractive candidate for the bioremediation of multiple contaminants in wastewaters.

\section{Acknowledgments}

This work was supported by the Ministry of Higher Education and Scientific Research of Tunisia. Special thanks to the Materials Engineering Department of the National School of Engineers of Sfax for help in FTIR spectroscopy analysis and the Digital Research Center of Sfax (CRNS) for support in AFM spectroscopy.

\section{Conflict of interest}

The authors declare no conflict of interest

\section{References}

Aksu, Z., 2005. Application of biosorption for the removal of organic pollutants: a review. Process Biochem. 40, 997-1026. https://doi.org/10.1016/j.procbio.2004.04.008

Ali, N., Hameed, A., Ahmed, S., 2009. Physicochemical characterization and Bioremediation perspective of textile effluent, dyes and metals by indigenous Bacteria. J. Hazard. Mater. 164, 322-328. https://doi.org/10.1016/j.jhazmat.2008.08.006

Ali, N.F., El-Mohamedy, R.S.R., 2012. Microbial decolourization of textile waste water. J. Saudi Chem. Soc. 16, 117-123. https://doi.org/10.1016/j.jscs.2010.11.005 
402

403

404

405

406

407

408

409

410

Anwar, F., Hussain, S., Ramzan, S., Hafeez, F., Arshad, M., Imran, M., Maqbool, Z., Abbas, N., 2014. Characterization of Reactive Red-120 Decolorizing Bacterial Strain Acinetobacter junii FA10 Capable of Simultaneous Removal of Azo Dyes and Hexavalent Chromium. Water. Air. Soil Pollut. 225. https://doi.org/10.1007/s11270$\underline{014-2017-7}$

Aryal, M., Liakopoulou-Kyriakides, M., 2015. Bioremoval of heavy metals by bacterial biomass. Environ. Monit. Assess. 187. https://doi.org/10.1007/s10661-014-4173-Z

Ayangbenro, A., Babalola, O., 2017. A New Strategy for Heavy Metal Polluted Environments: A Review of Microbial Biosorbents. Int. J. Environ. Res. Public. Health 14, 94. https://doi.org/10.3390/ijerph14010094

Ben Mansour, H., Mosrati, R., Corroler, D., Ghedira, K., Barillier, D., Chekir, L., 2009. In vitro mutagenicity of Acid Violet 7 and its degradation products by Pseudomonas putida mt-2: Correlation with chemical structures. Environmental Toxicology and Pharmacology 27, 231-236. https://doi.org/10.1016/j.etap.2008.10.008

Bernhoft, R.A., 2013. Cadmium Toxicity and Treatment. Sci. World J. 2013, 1-7. https://doi.org/10.1155/2013/394652

Beveridge, T.J., Murray, R.G., 1980. Sites of metal deposition in the cell wall of Bacillus subtilis. J. Bacteriol. 141, 876-887.

Boggs, M., Jiao, Y., Dai, Z., Zavarin, M., Kersting, A., 2016. Plutonium Interactions with Pseudomonas sp. and its Extracellular Polymeric Substances. Applied and Environmental Microbiology 82, AEM.02572-16. https://doi.org/10.1128/AEM.02572-16 
416 Chakravarty, R., Banerjee, P.C., 2008. Morphological changes in an acidophilic bacterium induced by heavy metals. Extremophiles 12, 279-284. https://doi.org/10.1007/s00792007-0128-4

Chao, Y., Zhang, T., 2011. Optimization of fixation methods for observation of bacterial cell morphology and surface ultrastructures by atomic force microscopy. Appl. Microbiol.

Durai, G., Rajasimman, M., 2011. Biological Treatment of Tannery Wastewater - A Review.

J. Environ. Sci. Technol. 4, 1-17. https://doi.org/10.3923/jest.2011.1.17

Feki-Tounsi, M., Olmedo, P., Gil, F., Khlifi, R., Mhiri, M.-N., Rebai, A., Hamza-Chaffai, A., 2013. Cadmium in blood of Tunisian men and risk of bladder cancer: interactions with arsenic exposure and smoking. Environ. Sci. Pollut. Res. 20, 7204-7213. https://doi.org/10.1007/s11356-013-1716-8 
452

457

458

Giovanella, P., Cabral, L., Costa, A.P., de Oliveira Camargo, F.A., Gianello, C., Bento, F.M., 2017. Metal resistance mechanisms in Gram-negative bacteria and their potential to remove $\mathrm{Hg}$ in the presence of other metals. Ecotoxicol. Environ. Saf. 140, 162-169. https://doi.org/10.1016/j.ecoenv.2017.02.010

Gui, M., Chen, Q., Ma, T., Zheng, M., Ni, J., 2017. Effects of heavy metals on aerobic denitrification by strain Pseudomonas stutzeri PCN-1. Appl. Microbiol. Biotechnol. 101, 1717-1727. https://doi.org/10.1007/s00253-016-7984-8

Gupta, P., Diwan, B., 2017. Bacterial Exopolysaccharide mediated heavy metal removal: A Review on biosynthesis, mechanism and remediation strategies. Biotechnol. Rep. 13, 58-71. https://doi.org/10.1016/j.btre.2016.12.006

Hansda, A., Kumar, V., Anshumali, 2016. A comparative review towards potential of microbial cells for heavy metal removal with emphasis on biosorption and bioaccumulation. World J. Microbiol. Biotechnol. 32. https://doi.org/10.1007/s11274$\underline{016-2117-1}$

Huang, G., Wang, W., Liu, G., 2015. Simultaneous chromate reduction and azo dye decolourization by Lactobacillus paracase CL1107 isolated from deep sea sediment. J. Environ. Manage. 157, 297-302. https://doi.org/10.1016/j.jenvman.2015.04.031

Huang, W., Liu, Z., 2013. Biosorption of $\mathrm{Cd}(\mathrm{II}) / \mathrm{Pb}$ (II) from aqueous solution by biosurfactant-producing bacteria: Isotherm kinetic characteristic and mechanism 
466

467

468

469

470

471

472

473

474

475

476

477

478

479

480

481

482

483

484

485

486

487

488

studies. Colloids Surf. B Biointerfaces 105, 113-119.

https://doi.org/10.1016/j.colsurfb.2012.12.040

Imran, M., Shaharoona, B., Crowley, D.E., Khalid, A., Hussain, S., Arshad, M., 2015. The stability of textile azo dyes in soil and their impact on microbial phospholipid fatty acid profiles. Ecotoxicol. Environ. Saf. 120, 163-168. https://doi.org/10.1016/j.ecoenv.2015.06.004

Kolekar, Y.M., Kodam, K.M., 2012. Decolorization of textile dyes by Alishewanella sp.

sp. KMK6. Appl Microbiol Biotechnol 95, 521-529. https://doi.org/10.1007/s00253-011$\underline{3698-0}$

Lacave, J.M., Bilbao, E., Gilliland, D., Mura, F., Dini, L., Cajaraville, M.P., Orbea, A., 2020. Bioaccumulation, cellular and molecular effects in adult zebrafish after exposure to cadmium sulphide nanoparticles and to ionic cadmium. Chemosphere 238, 124588. https://doi.org/10.1016/j.chemosphere.2019.124588

Louati, I., Hadrich, B., Nasri, M., Belbahri, L., Woodward, S., Mechichi, T., 2019. Modelling of Reactive Black 5 decolourization in the presence of heavy metals by the newly isolated Pseudomonas aeruginosa strain Gb30. Journal of Applied Microbiology 126, 1761-1771. https://doi.org/10.1111/jam.14262

Mahmood, S., Khalid, A., Arshad, M., Mahmood, T., Crowley, D.E., 2015. Detoxification of azo dyes by bacterial oxidoreductase enzymes. Crit. Rev. Biotechnol. 1-13. https://doi.org/10.3109/07388551.2015.1004518 
507

Maqbool, Z., Hussain, S., Ahmad, T., Nadeem, H., Imran, M., Khalid, A., Abid, M., MartinLaurent, F., 2016. Use of RSM modeling for optimizing decolorization of simulated textile wastewater by Pseudomonas aeruginosa strain ZM130 capable of simultaneous removal of reactive dyes and hexavalent chromium. Environ. Sci. Pollut. Res. 23, 11224-11239. https://doi.org/10.1007/s11356-016-6275-3

Mishra, A., Malik, A., 2014. Metal and dye removal using fungal consortium from mixed waste stream: Optimization and validation. Ecol. Eng. 69, 226-231. https://doi.org/10.1016/j.ecoleng.2014.04.007

Mohamed Fahmy Gad El-Rab, S., Abdel-Fattah Shoreit, A., Fukumori, Y., 2006. Effects of Cadmium Stress on Growth, Morphology, and Protein Expression in Rhodobacter capsulatus B10. Biosci. Biotechnol. Biochem. 70, 2394-2402. https://doi.org/10.1271/bbb.60122

Naik, M.M., Dubey, S.K., 2011. Lead-Enhanced Siderophore Production and Alteration in Cell Morphology in a Pb-Resistant Pseudomonas aeruginosa Strain 4EA. Curr. Microbiol. 62, 409-414. https://doi.org/10.1007/s00284-010-9722-2

Pavlaki, M.D., Araújo, M.J., Cardoso, D.N., Silva, A.R.R., Cruz, A., Mendo, S., Soares, A.M.V.M., Calado, R., Loureiro, S., 2016. Ecotoxicity and genotoxicity of cadmium in different marine trophic levels. Environ. Pollut. 215, 203-212. https://doi.org/10.1016/j.envpol.2016.05.010 
Pizzaia, D., Nogueira, M.L., Mondin, M., Carvalho, M.E.A., Piotto, F.A., Rosario, M.F., Azevedo, R.A., 2019. Cadmium toxicity and its relationship with disturbances in the cytoskeleton, cell cycle and chromosome stability. Ecotoxicology. https://doi.org/10.1007/s10646-019-02096-0

Ramya, D., Thatheyus, A.J., 2018. Microscopic Investigations on the Biosorption of Heavy Metals by Bacterial Cells: A Review. Sci. Int. 6, 11-17. https://doi.org/10.17311/sciintl.2018.11.17

Rani, A., Kumar, A., Lal, A., Pant, M., 2014. Cellular mechanisms of cadmium-induced toxicity: a review. Int. J. Environ. Health Res. 24, 378-399. https://doi.org/10.1080/09603123.2013.835032

Ruta, L., Paraschivescu, C., Matache, M., Avramescu, S., Farcasanu, I.C., 2010. Removing heavy metals from synthetic effluents using "kamikaze" Saccharomyces cerevisiae cells. Appl. Microbiol. Biotechnol. 85, 763-771. https://doi.org/10.1007/s00253-009$\underline{2266-3}$

Sarker, B., Baten, M.A., Haque, M.E.-U., Das, A., Hossain, A., Hasan, M.Z., 2015. Heavy Metals' Concentration in Textile and Garments Industries' Wastewater of Bhaluka Industrial Area, Mymensingh, Bangladesh. Curr. World Environ. 10, 61-66. https://doi.org/10.12944/CWE.10.1.07 
Solís, M., Solís, A., Pérez, H.I., Manjarrez, N., Flores, M., 2012. Microbial decolouration of azo dyes: A review. Process Biochem. 47, 1723-1748. https://doi.org/10.1016/j.procbio.2012.08.014

Soni, R.K., Acharya, P.B., Modi, H.A., 2014. Effect of some metals on growth of Pseudomonas aeruginosa ARSKS20 and its decolorization ability of reactive red 35. Int J Curr Microbiol Appl Sci 3, 411-419.

Tarangini, K., 2009. Biosorption of heavy metals using individual and mixed cultures of Pseudomonas aeruginosa and Bacillus subtilis. National institute of technology, rourkela.

Taştan, B.E., Ertuğrul, S., Dönmez, G., 2010. Effective bioremoval of reactive dye and heavy metals by Aspergillus versicolor. Bioresour. Technol. 101, 870-876. https://doi.org/10.1016/j.biortech.2009.08.099

Tchounwou, P.B., Yedjou, C.G., Patlolla, A.K., Sutton, D.J., 2012. Heavy Metal Toxicity and the Environment, in: Luch, A. (Ed.), Molecular, Clinical and Environmental Toxicology. Springer Basel, Basel, pp. 133-164. https://doi.org/10.1007/978-3-7643$\underline{8340-4 \_6}$

Zeng, X., Tang, J., Liu, X., Jiang, P., 2009. Isolation, identification and characterization of cadmium-resistant Pseudomonas aeruginosa strain E1. J. Cent. South Univ. Technol. 16, 416-421. https://doi.org/10.1007/s11771-009-0070-y 
Fig.1

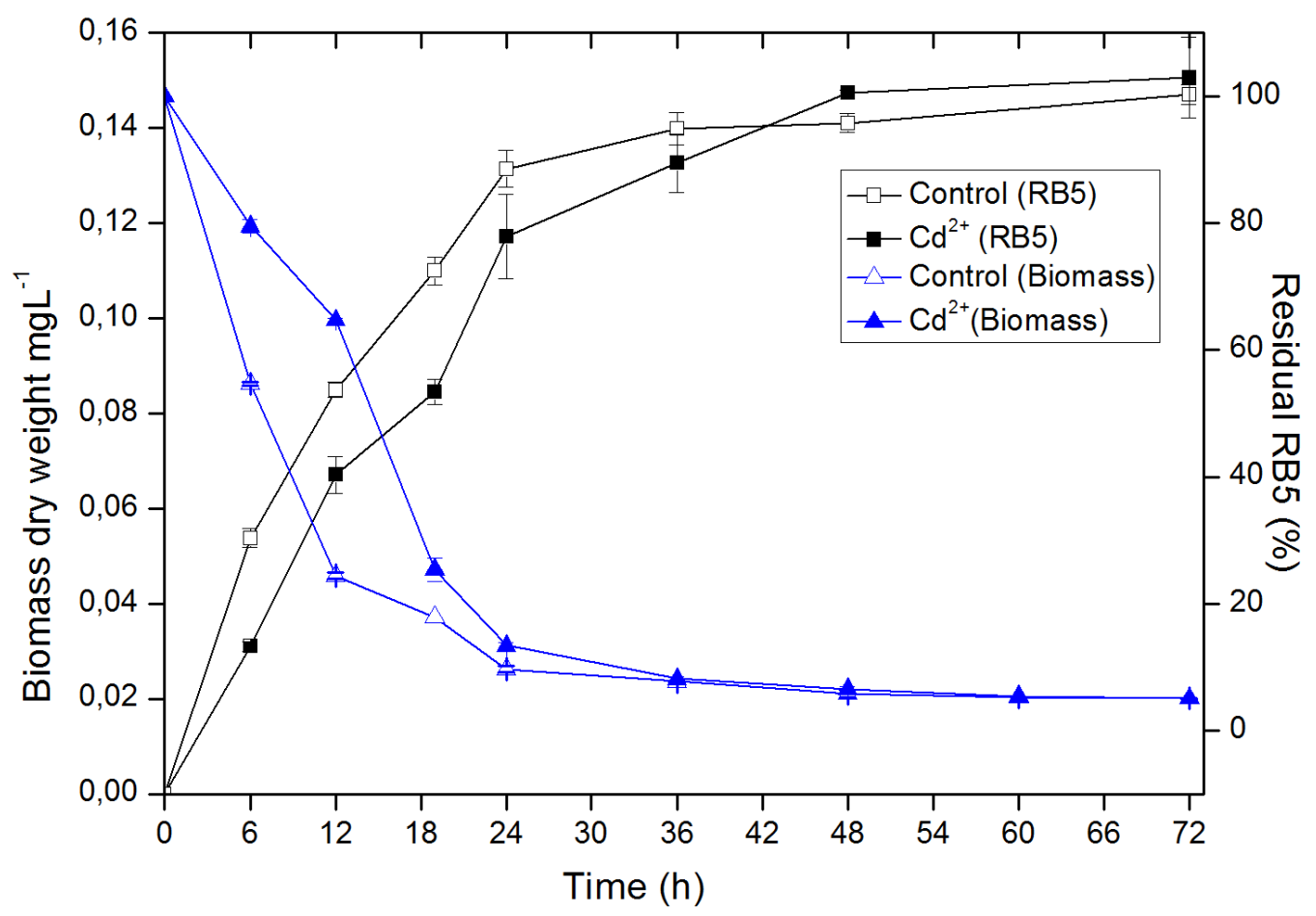
Liakopoulou-Kyriakides, M., 2007. Comparative study of Cd(II) and Cr(VI) biosorption on Staphylococcus xylosus and Pseudomonas sp. in single and binary mixtures. Bioresour. Technol. 98, 2859-2865. https://doi.org/10.1016/j.biortech.2006.09.043

Ziagova, M., Dimitriadis, G., Aslanidou, D., Papaioannou, X., Litopoulou Tzannetaki, E.,

567

568 Figure 1: Bacterial dry weight (left) and decolorization kinetics of RB5 (right) in presence ( 

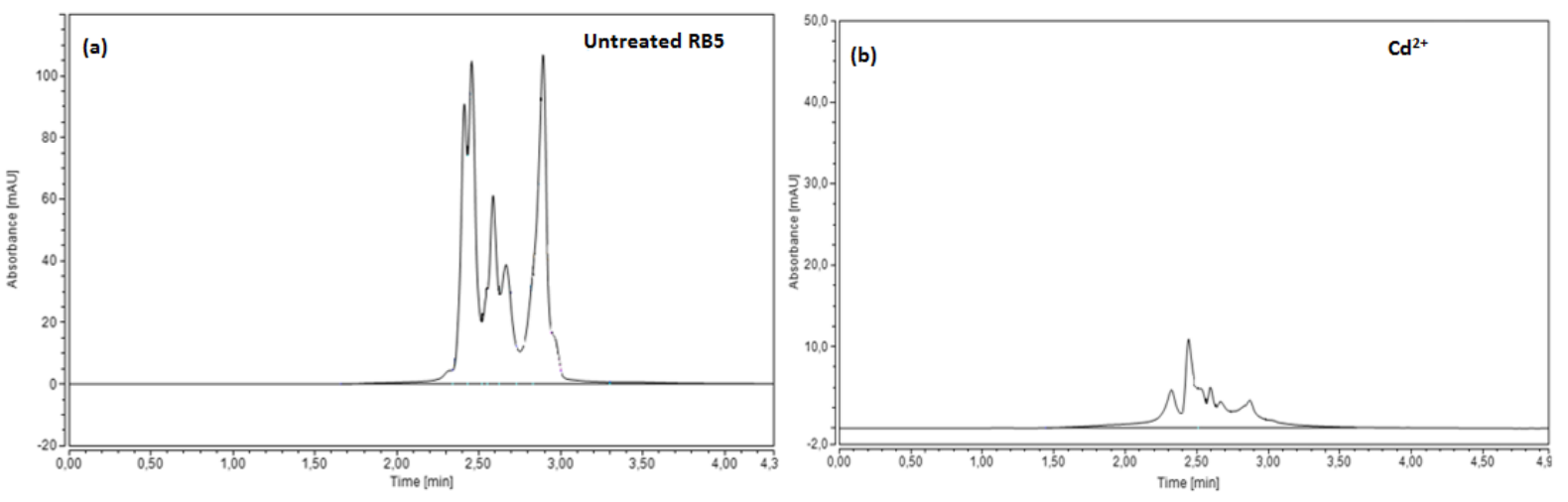

573

574 Figure 2: HPLC chromatograms of untreated RB5 (a) and its biodegradation products in

575 presence of cadmium (b). HPLC conditions: C-18 column at room temperature with a water / 576 methanol $(60 / 40 \%)$ flow rate of $1 \mathrm{~mL} \mathrm{~min}^{-1}$.

\section{$578 \quad$ Fig.3}




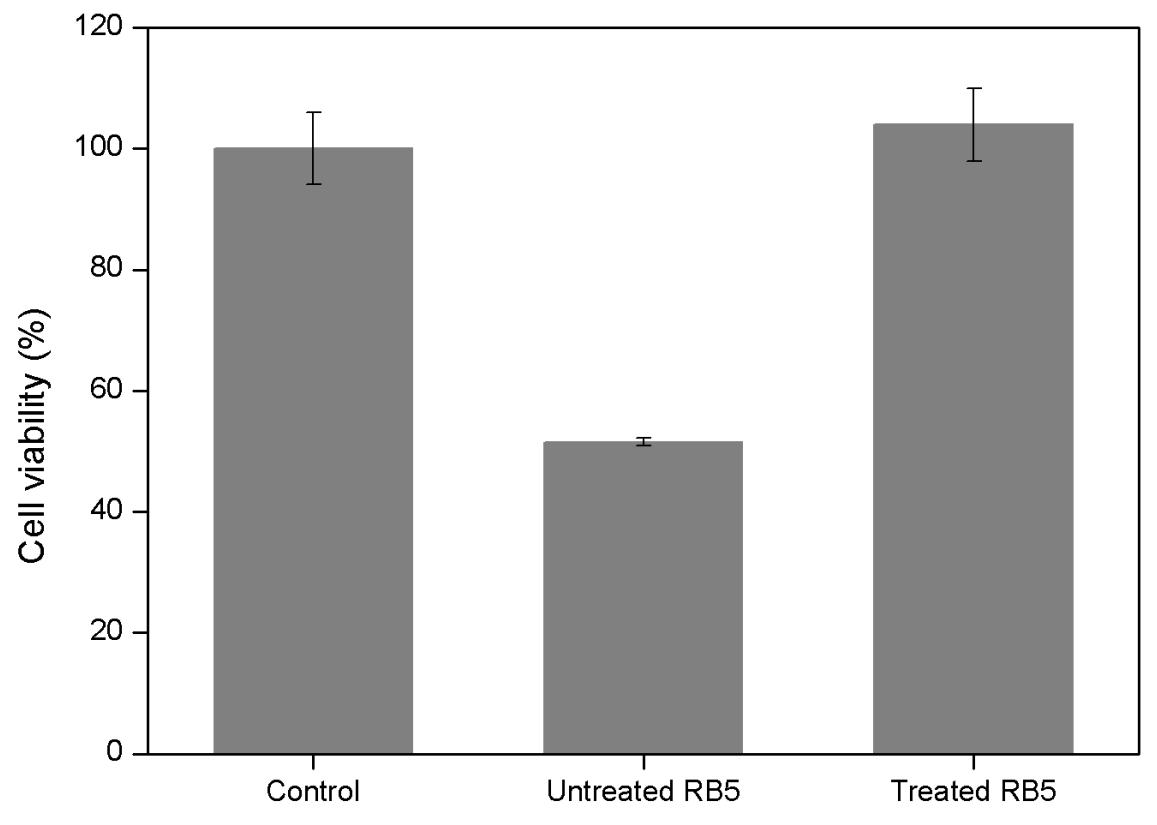

579

580 Figure 3: Cytotoxic effects of RB5 on HEK293 cells before biodegradation (Untreated RB5)

581 and after bacterial treatment with P. aeruginosa strain Gb30 (Treated RB5) compared to normal 582 cells (control).

$583 \quad$ Fig.4 


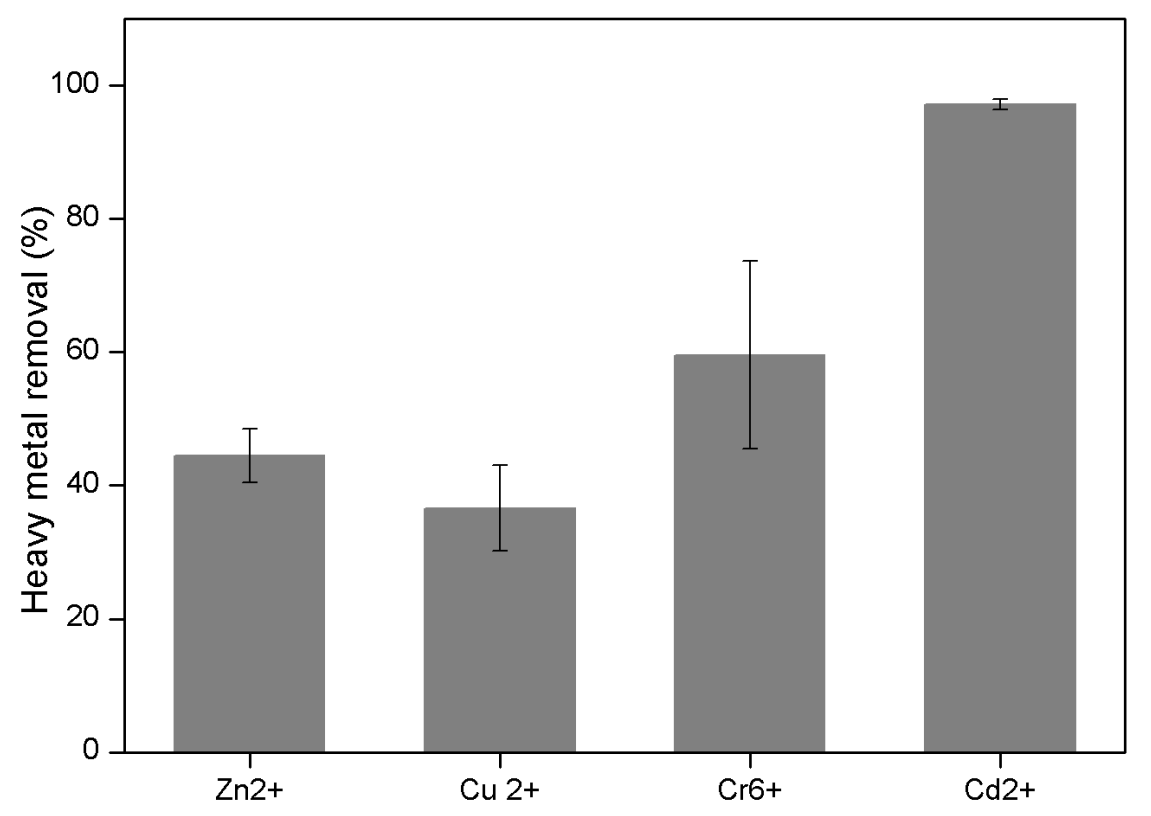

584

585 Figure 4: Removal of heavy metals from $P$. aeruginosa Gb30 cultures containing a mixture of

$586 \mathrm{Cr}^{6+}, \mathrm{Cd}^{2+}, \mathrm{Cu}^{2+}$ and $\mathrm{Zn}^{2+}$ at $0.115,0.157,0.401$ and $0.381 \mathrm{~m} \mathrm{~mol} \mathrm{~L}^{-1}$, respectively, determined

587 using atomic absorption. 


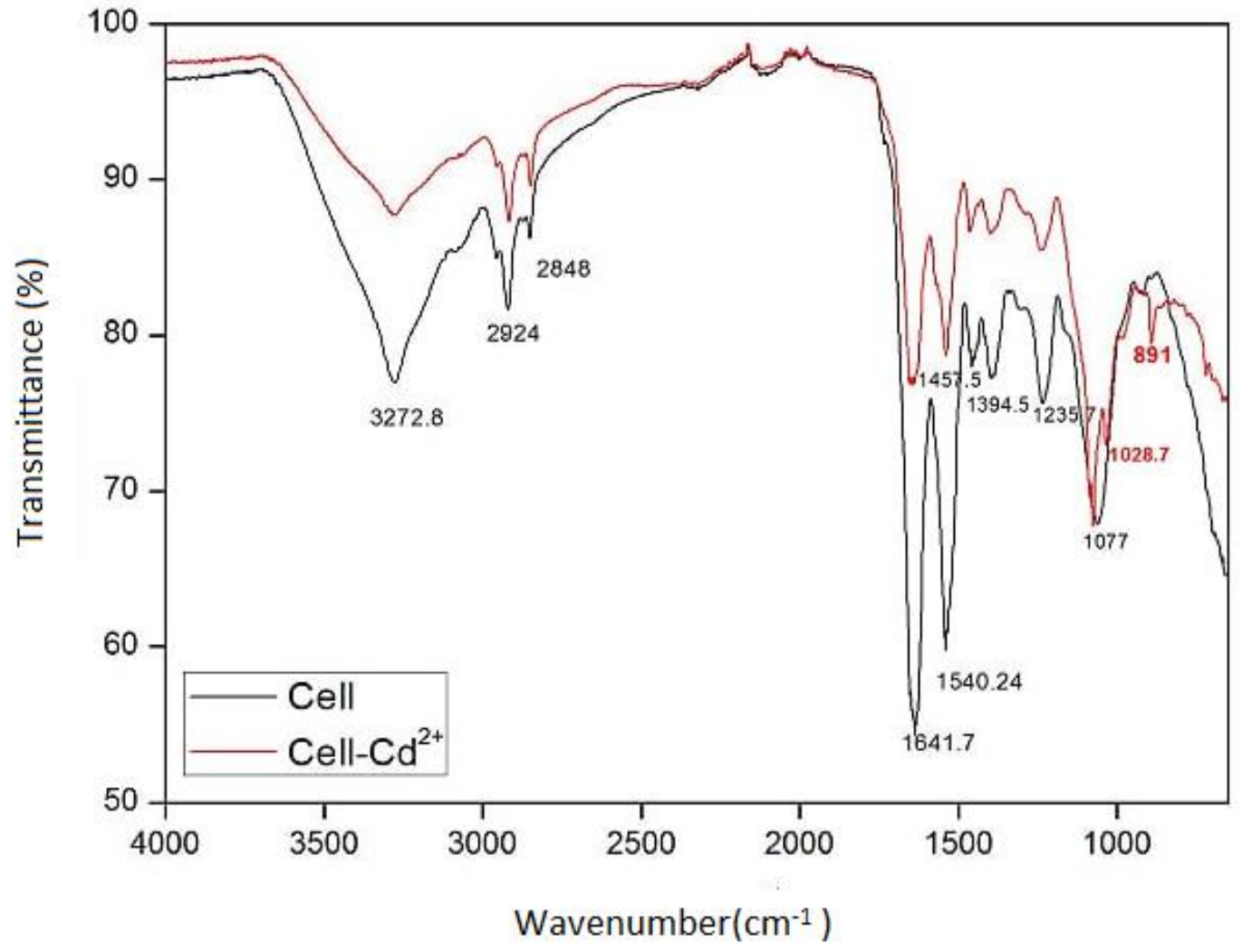

Figure 5: FTIR spectra of Pseudomonas aeruginosa Gb30 biomass before (Black line) and after exposure to $\mathrm{Cd}$ (Red line). 

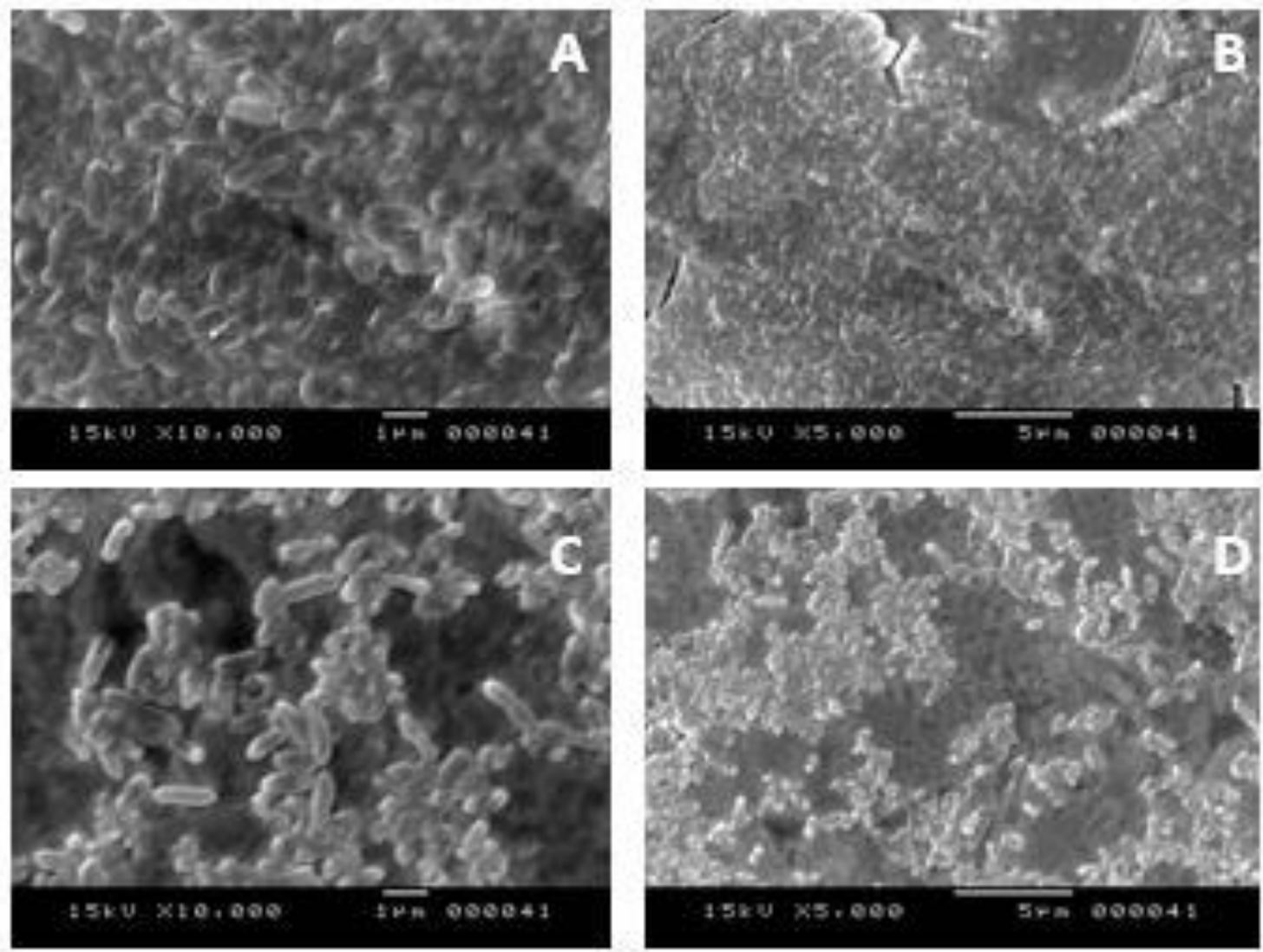

593

594

595 Figure 6: SEM micrographs of Pseudomonas aeruginosa in Cd-free medium (A, B) and Cd-

596 containing medium (C, D). 
599 Table 1: Kinetic constants and statistical parameters of cadmium biosorption onto biomass of $600 \quad$ Pseudomonas aeruginosa Gb30.

\begin{tabular}{lccccccc}
\hline Model & $\mathrm{k}_{1}\left(\mathrm{~h}^{-1}\right)$ & $\mathrm{k}_{2}\left(\mathrm{mg} \mathrm{g}^{-1} \mathrm{~h}\right)$ & $\mathrm{q}_{\mathrm{eq}}\left(\mathrm{mg} \mathrm{g}^{-1}\right)$ & $\mathrm{R}^{2}$ & $\mathrm{R}^{2}$ Adj & SSE & RMSE \\
\hline Pseudo-first order & 0.1368 & - & 548.2 & 0.9892 & 0.9866 & 2571 & 25.35 \\
Pseudo-second order & - & 0.0005161 & 583.7 & 0.9774 & 0.9717 & 5407 & 36.77 \\
\hline
\end{tabular}

